\title{
Semeando proposições heréticas no Brasil colonial: contesto, logo propago (XVI-XVIII)
}

Sowing heretical propositions in colonial Brazil: contest, then propagate (XVI-XVIII)

Diogo Tomaz Pereira*

ufjf.diogo@gmail.com

Resumo: O artigo busca apresentar e analisar crimes de proposição herética ocorridos no Brasil entre os séculos XVI e XVIII. Através da opção por uma escala de observação reduzida pretendo não só reconstruir uma história individual como também contar essa história reconstruindo o mundo intelectual, moral e fantástico desses presos. A fala garantia a realidade do pensamento, era assim que a Inquisição enxergava tudo o que era dito pelos propositores. Compreendiam a fala como uma extensão do pensamento e apresentação de convicções internas. Com fontes ricas em detalhes, busco mostrar como as proposições poderiam influenciar outras pessoas e desencadear novos escândalos e como a circulação de livros proibidos na Colônia foi importante para a propagação desse delito.

Palavras-Chave: proposições heréticas, Inquisição portuguesa, sociedade colonial

Abstract: This article aims to present and analyze crimes of heretical proposition committed in Brazil, between the sixteenth and eighteenth centuries. Through a reduced scale of observation I intend to reconstruct an individual story, but also rebuild the intellectual, moral and fantastic world of these prisoners. Anything said, used to be considered an extension of thoughts, so I seek to show, through richly detailed sources, how such propositions could influence others and unleash new scandals. As well as the circulation of banned books at the Colony was important for the spread of such crime.

Keywords: heretical propositions, Portuguese inquisition, colonial society 


\section{Introdução}

Fui em pontos de fé denunciado, Igual Susana, acusada dos dois velhos Com falsos testemunhos, aparelhos Que eu creio a definido e abraçado Da Igreja, na escritura e evangelhos Nos sacramentos, ritos, bons conselhos

E costumes, que sempre há praticado. Professo o credo e abraço a Santa Doutrina Que a Igreja segue, e o que ela detesta Eu detesto, e quanto ela abomina. Para ser igual Susana só me resta Que aos falsários castigue a mão divina, Mas Deus lhe dê melhor sorte do que esta.

\section{Romão Fagundes do Amaral, Inquisição de Lisboa. Processo 12.958.}

Sobre o período Moderno, Mikhail Bakhtin buscou analisar A cultura popular na Idade Média e no Renascimento a linguagem e cultura de François Rabelais sugestionado da noção "carnavalesca" de mundo. Rabelais é considerado, apesar de seu relativo desconhecimento, como um dos maiores gênios da literatura pelos especialistas europeus, principalmente, em se tratando do século XVI. O que o difere de um Cervantes, Shakespeare, Boccaccio é seu uso preferencial pelas fontes populares, que determinariam suas imagens e criações artísticas. Para Bakhtin, o carnaval era um momento em que as hierarquias, as regras e certos tabus se desfaziam, abrindo lugar às diversas formas de expressão e linguagem. Essas novas formas de comunicação produziram também inéditos modelos linguísticos. $\mathrm{O}$ clima de festa, o caráter universal, a ideia utópica e a concepção profunda do mundo fizeram com que o Carnaval da Idade Média diferencie-se das relações modernas de amizade ou do próprio carnaval moderno. "A linguagem familiar da praça pública caracteriza-se pelo uso frequente de grosserias, ou seja, de expressões e palavras injuriosas, às vezes bastante longas e complicadas" (BAKHTIN, 1987, p.15). Tanto os juramentos, como os demais fenômenos verbais e suas obscenidades, foram transplantados para a linguagem familiar, único lugar que sobrou para sua manifestação. Esta se tornou, por assim dizer, um repositório das expressões verbais proibidas e eliminadas da comunicação da praça. Através do grotesco e do escárnio, um novo sentido era concedido às palavras e aos ritos sagrados, "participando-lhes de seu cotidiano no mais baixo e desqualificado dos atos e expressões" (MATTOS, 2014, p. 133).

O problema da salvação - pela obra, graça ou mérito -, os dogmas canônicos sobre a virgindade de Maria antes, durante e depois do parto e a eficácia dos santos, ou mesmo questões que envolviam a ideia de pecado na fornicação com várias pessoas, era assunto da maior importância para teólogos católicos e protestantes (MATTOS, 2014, p.137).

Partindo das análises feitas por Bakhtin, durante estudos realizados sobre a Inquisição Moderna em Portugal, a blasfêmia foi muito confundida com outro delito bastante perseguido pelo Tribunal português, a proposição herética. As proposições heréticas eram críticas, questionamentos ou indagações realizadas contra a Igreja ou aos seus membros. Eram expressões ditas por algum cristão ou não, "buscando uma reflexão crítica sobre os artigos da fé que constituíam a essência da religião católica" (ALEJANDRE, 1998, p.35). Levado a efeito de comparação, blasfêmias são expressões verbais do cotidiano atribuídas ao escárnio, à chacota ou a falta de conhecimento. A blasfêmia só vem a se tornar uma proposição herética, "quando o blasfemo crê naquilo que diz e tem a intenção de propagálo" (MENEZES, 2010, p. 71).

O primeiro processado pela Inquisição portuguesa no Brasil foi pelo delito de proposição herética e esse desfortuno privilégio recaiu sobre Pero do Campo 
Tourinho (ANTT/IL, processo 8821), preso em Porto Seguro no ano de 1546. Segundo afirmavam os denunciantes, Pero do Campo precisava ser preso e processado devido às "muitas heresias e abominações que nesta vila dizia e fazia contra Deus nosso Senhor e contra a Santa Madre Igreja" (DIAS, 1924, p.271). Tourinho era natural de Viana do Castelo, em Portugal, e recebeu em 1534, de d. João III "foral que o nomeava primeiro Capitão Donatário da Capitania de Porto Seguro" (ASSIS, 2013, p.58). Três anos antes de ser preso, foi denunciado por desrespeitar as normas da moral e por proferir heresias como "se Deus o não favorecia e ajudava que diria que a fé dos turcos ou mouros era a boa" ou "que era melhor ir ver o Diabo do que Deus" e também "que enforcaria, justiçaria e cortaria as coroas em metades a todos os padres", entre outras. Ao ser detido, segundo o próprio Tourinho, "sua prisão foi uma conjuração feita por alguns moradores que eram seus inimigos" (DIAS, 1924, p. 284).

Diante do escrivão da Santa Inquisição, afirmou que os depoimentos das testemunhas que constavam nos Autos eram falsos, sendo fabricados através de subornos. Revelou que era "muito bom católico cristão e muito desejoso de aumentar nossa santa fé nas ditas partes e gentios do Brasil" e, por isso mesmo, suplicava ao Tribunal que o despachasse com rapidez, revendo o processo armado contra ele na Capitania de Porto Seguro pela conspiração de seus inimigos capitais (DIAS, 1924, p. 284).

Francisco Cancela corrobora a ideia de conspiração formulada por Tourinho; o donatário foi preso devido à junção de importantes homens incomodados com o seu comportamento.

Tourinho foi preso por uma ação planejada pelos homens mais importantes da Vila de Porto Seguro: os juizes ordinários Pero Escornio Drumondo e Pero Ames Vicente; o capelão do Duque de Aveio, Manuel Colaço; os padres João Bezerra e frei Jorge; e o vigário da Vila, reverendo Bernardo de Aureajac. A pri- são foi explicada como decorrência do cumprimento das regras da Santa Inquisição, que orientava os bons cristãos a prender e encaminhar para devassa as pessoas que desrespeitassem os santos preceitos da fé católica (CANCELA, 2010, p. 7).

Bem como afirmavam os acusadores, Pero do Campo precisava ser preso e processado devido às "muitas heresias blasfemas e abominações que nesta vila dizia e fazia contra Deus nosso Senhor e contra a Santa Madre Igreja" (CANCELA, 2010, p.271). Ao final de seu processo Pero do Campo Tourinho é absolvido dos delitos religiosos e se livra das penas inquisitórias; sua sentença não foi comparecer ao auto de fé, nem traumática como o exílio nas posses portuguesas de Ultramar. Todavia, não foi amena: "ficou proibido de deixar Portugal e impedido para sempre de retornar à Capitania de Porto Seguro" (ASSIS, 2013, p. 58) além de pagar uma fiança de mil cruzeiros.

Ainda sobre a conceptualização das proposições heréticas, para Stuart Schwartz, "eram declarações que potencialmente indicavam concepções erradas em questões de fé e que eram, portanto, pecaminosas" (SCHWARTZ, 2009, p. 39). Pior do que colocarem a alma do propositor (como denomino doravante os presos pelo crime de proposição herética) em risco, as proposições poderiam influenciar outras pessoas e desencadear novos escândalos. A proposição herética era algo pensado, muitas vezes dito por pessoas instruídas como, por exemplo, membros do clero, com o intuito de romper, de gerar novos pensamentos, que com apenas um só golpe, pareciam querer lançar por terra todo o edifício construído e mantido pela fé e religião. Proferiam as palavras em seu perfeito juízo, não estavam bêbados nem fora de si. 


\section{Semeando proposições heréticas}

Enquanto a ironia, a zombaria e os palavrões serviam aos colonos como uma forma de diversão e até de denuncia às dificuldades de assistência que sofriam, à forte repressão da Inquisição, “o Santo Oficio respondia e refutava com ódio e sisudez. O processo e as representações do auto da fé eram suas armas mais eficazes" (MATTOS, 2014, p. 134). Com relação às proposições heréticas, essas armas buscavam determinar se a expressão havia sido usada de maneira adequada e, sobretudo, "se exteriorizava uma crença ou um propósito relacionado com questões de fé" (ALEJANDRE, 1998, p. 45). Caso este dos processados que julgavam qual estado era o melhor, o dos casados ou o dos religiosos, mas, diferente dos presos por blasfêmias que disseram coisas semelhantes, para se configurar como uma proposição herética deveria ser afirmada com uma devida convicção e mantida a posteriori. O que foi feito por Francisco Mendes, um mercador de São Lourenço, capitania de Pernambuco em 1594. Denunciado pelo também mercador Fabiam Lopes, que relatou um dia estarem reunidos na varanda da casa de um amigo, conversando sobre a vida dos casados e dos religiosos, Francisco aos gritos disse que "o estado dos casados era melhor que o dos religiosos" (ANTT/IL, processo 8502, fl. 8). Após ser repreendido, afirmou que era óbvio o que dizia, pois os casados podiam dormir com suas mulheres. Os outros amigos, Pero Lopes e Manoel Garro quando foram chamados para testemunhar, confirmaram o que Fabiam havia denunciado. Na primeira sessão de seu interrogatório, Francisco Mendes confirmou e repetiu os dizeres pelos quais era processado, mas, salientou que não tinha a intenção de atacar ou denegrir a figura de ninguém; que essas eram as ideias que tinha por convicção. Perguntado nas três seções de seu interrogatório (julho, agosto e setembro) se estava arrependido, respondeu "que não, pois era aquilo que acredita- va, pois, se não, Deus não teria criado o homem e a mulher" (ANTT/IL, processo 8502, fl. 11). Considerado culpados por seus erros, foi sentenciado a "ir ao auto da fé descalço com a cabeça descoberta, cingido com uma corda e uma vela acesa na mão, abjuração de leve, instrução na fé católica, penitências espirituais e pagamento de oitenta cruzados para as despesas do Santo Oficio" (ANTT/IL, processo 8502, fl. 125). Outro caso semelhante no mesmo ano, mas ocorrido na cidade de Olinda, foi do lavrador Pedro Lopes denunciado ao Santo Oficio por espalhar pelas ruas "ser melhor o estado dos casados que o dos religiosos" (ANTT/IL, processo 11111 , fl. 3). Inúmeras foram as pessoas que depuseram contra o lavrador, ao todo seis indivíduos confirmaram terem ouvido as mesmas coisas. Logo nas primeiras sessões de seu interrogatório, Pedro Lopes dizia não compreender o motivo de estar ali, "pois o que dizia não poderia ser qualificado como uma heresia” (ANTT/IL, processo 11111, fl. 48) já que o estado dos casados "fora o primeiro criado por Deus" (ANTT/ IL, processo 11111, fl. 95). Após três sessões de interrogatórios (junho, julho e agosto) Pedro dizia ter "compreendido" o que o visitador Heitor Furtado queria transmitir e ensinar a ele, mas, que "tinha ainda convicção do que havia dito" (ANTT/IL, processo 11111, fl. 95). Questionado pelo Tribunal se voltaria a propagar as ditas proposições, respondeu que "em respeito a Deus, e somente a Deus, não voltaria a dizêlas" (ANTT/IL, processo 11111, fl. 96). Como sentença foi determinada a ida "ao auto da fé em corpo, com a cabeça descoberta, com uma vela acesa na mão, que sofresse abjuração de leve suspeita na fé, penas e penitências espirituais" (ANTT/IL, processo 11111, fl. 96).

As proposições heréticas, as criticas, as indagações e os questionamentos alcançavam certa profundidade, ao propiciarem uma relação entre heterodoxia e espiritualidade. "Mas, por outro lado, constituíam feroz 
contestação à autoridade da Igreja e do Estado e, por isso mesmo, à Inquisição" (MATTOS, 2014, p. 137). Para o Tribunal do Santo Oficio, um simples pensamento já bastava para se cometer o pecado; a palavra que se manifestaria desta reflexão provocaria escândalos e indignação. “A linguagem familiar da praça pública caracteriza-se pelo uso frequente de grosserias, ou seja, de expressões e palavras injuriosas, às vezes bastante longas e complicadas" (BAKHTIN, 1987, p. 15). Tanto os juramentos como os demais fenômenos verbais e suas obscenidades, ao serem eliminados da linguagem oficial foram transplantados para a linguagem familiar, único lugar que sobrou para sua manifestação. Esta tornou-se, por assim dizer, um repositório das expressões verbais proibidas e eliminadas da comunicação oficial. Através do grotesco e do escárnio, um novo sentido era concedido às palavras e aos ritos sagrados, "participando-lhes de seu cotidiano no mais baixo e desqualificado dos atos e expressões" (MATTOS, 2014, p. 133).

O problema da salvação - pela obra, graça ou mérito -, os dogmas canônicos sobre a virgindade de Maria antes, durante e depois do parto e a eficácia dos santos, ou mesmo questões que envolviam a ideia de pecado na fornicação com várias pessoas, era assunto da maior importância para teólogos católicos e protestantes (MATTOS. 2014, p. 137).

Após a descoberta de ouro na região das Minas Gerais no final do século XVII, que se consolidou no decorrer do XVIII, muitas pessoas se aventuraram por essas terras atraídas pela possibilidade de enriquecimento rápido. $\mathrm{O}$ vertiginoso crescimento populacional e próspero fluxo econômico oriundos da exploração do ouro, demandaram a criação das vilas de São João del-
Rei (1713-1714) e São José del-Rei (1718), "propiciando um desenvolvimento econômico e cultural notável" (VILLALTA, 1988, p. 12). Dentre os vários agentes históricos que vieram para as Minas, um caso específico me chamou a atenção, o caso do Sargento Mor Romão Fagundes do Amaral.

Romão Fagundes do Amaral, denunciado à Inquisição em 1795 pelo Padre Manoel Ferreira Godinho por proferir palavras escandalosas e heréticas contra o Santo Oficio e os seus oficiais, teve uma infância simples. Na juventude, viveu pelas ruelas da cidade de São Sebastião do Rio de Janeiro "vendendo galinhas e toucinhos" (ANTT, processo 12.958, fl. 230), foi nessa mesma época que recebeu o apelido de "Poeta de Trás da Serra”, por gostar de escrever poesias e sonetos. Era autodidata, nunca frequentou uma escola, aprendeu a ler e escrever sozinho pelas cartilhas de catecismo escritas por São Roque de Montpellier ${ }^{1}$ e pelas recriações filosóficas do Padre Teodoro de Almeida ${ }^{2}$ como "Horas Marianas", "Combate Espiritual" entre outros. Ao se mudar para Mariana como exímio orador que era, ficou também conhecido como "o discípulo" dos filósofos iluministas Voltaire e Rousseau. O que o jovem garoto buscava, eram respostas que os padres não podiam ou não sabiam lhe dar, "buscava compreender, desde pequeno, à sua maneira novas explicações para a ordem natural das coisas, sempre que possível dissuadindo seus interlocutores a acreditar em suas teorias" (SOUSA, 2013, p. 22).

Quando adulto seu foco passou a ser o garimpo, tornando-se muito rico após encontrar ouro na freguesia de Santa Ana das Lavras do Funil, comarca de Rio das Mortes; onde comprou e se fixou em uma fazenda na

\footnotetext{
${ }^{1}$ São Roque é um santo da Igreja Católica, protetor contra a peste e padroeiro dos inválidos e cirurgiões. É também considerado por algumas comunidades católicas como protetor do gado contra doenças contagiosas.

${ }^{2}$ Teodoro de Almeida (1722-1804) foi um sacerdote católico, escritor e filósofo português, uma das mais expressivas figuras do iluminismo de Portugal.
} 
Mata do Senhor Bom Jesus dos Perdões. Chegou também ao posto de Sargento-Mor, porém, logo experimentou a ruína, sendo publicamente conhecido por seu falatório escandaloso. Após se tornar um homem rico, montou em sua fazenda uma biblioteca recheada de livros considerados heréticos ${ }^{3}$ e passou a reescrevê-los à partir de suas próprias ideias.

"Possuir livros na colônia estivera menos ligado à condição social do que a atividade que exercia" (VILLALTA, 1997, p. 332). Nas bibliotecas particulares encontravam-se muitos livros de caráter religioso, o que não impedia, porém, que títulos subversivos e suas ideias circulassem, sobretudo na passagem para o século XIX, rompendo progressivamente com a fé, a lei e o rei. De uma excelente oratória, Romão Fagundes tratava de assuntos filosóficos, matemáticos e teológicos; assim, passou a disseminar a duvida entre os próprios capelães da Igreja.

Os capelães eram uns pobres homens que tinham medo dele, os moradores também assim são, não somente pela verbosidade das suas palavras como pelas más entranhas de que é dotado que os inquieta e não sabia o que haviam de fazer respectiva às proposições heréticas que lhe ouviam (ANTT, processo 12958, fl. 5).

Diante das denúncias que o Santo Oficio ouviu, Romão foi acusado de proferir que "Maria não poderia ser virgem e que após ter dado a luz a Jesus, teria ficado 'boa' como qualquer mulher" (ANTT, processo, 12958, fl. 8). Dissera que não havia inferno nem purgatório, que aquilo era invenção dos padres para amedrontar as pessoas. Ainda teria dito que:

[...] o sumo pontifice era um homem como qualquer um e que não tinha poder para conceder indulgências e que quem nasceu para ir para o céu havia de ir, e quem nascera para ir para o inferno ha- via, ainda que o que fizesse más obras se tivesse de ir para o céu havia de ir (ANTT, processo 12958, fl. 5).

Romão também foi acusado de amancebar-se com uma mulata que chamavam de "Bará", dentro de sua própria casa e obrigando sua mulher a segurar uma vela para iluminar a cama enquanto tinham relações sexuais. Também por ter uma língua tão "afiada" e, por certa vez, ter estuprado uma menina de 8 anos de idade - que por muito pouco não faleceu -, fora espancado "e até lhe deceparam a mão direita pelo pulso" (ANTT, processo 12958, fl. 229). Mesmo após ser mutilado, atrevido, "respondia aos capelães com sonetos e poemas sarcásticos de sua autoria" (ANTT, processo 12958, fl. 77-78).

A população local enfurecida com o seu mal viver o apedrejou, obrigando-o a se calar e fugir novamente. Não bastasse isso, seu comportamento herético instigou aos moradores do arraial de Bom Jesus de Perdões a encaminhar um requerimento sobre os transtornos que causava. Em resposta, Romão Fagundes escreveu uma carta em sua defesa onde dizia o quanto era bom seguidor da religião católica e que tudo o que haviam ouvido nada mais era que intriga de seus vários inimigos que o invejavam. Procurou dissuadir o Vigário da Vara de São João del-Rei escrevendo-lhe uma outra carta "com vários sonetos e poemas enaltecendo a religião católica” (ANTT, processo 12958, fl. 82-82).

\section{Sem pecado concebida}

E a mãe de Deus dominante

Celebramos a memória

Notório da eterna glória

Da morte e culpa triunfante

Do espirito vivificante

Foi para esposa escolhida 
Com ele o seu filho unida

Impera do trono régio

Sendo para tal privilégio

Sem pecado concebido

(ANTT, processo 12958, fl. 92).

\section{A sempre inteira virgindade da mãe de Deus, antes do parto, no parto $e$ depois do parto}

Sobre a ordem geral da natureza

Vinda do Espirito Santo concebido

E sois cristo, da virgem foi nascido,

Sem violar a virginal pureza;

Qual do vidro e cristal firme a dureza,

Penetra e passa o sol esclarecido,

Sem que algum desses fique dividido,

tal de Maria foi sempre a inteiração

o Deus que teve em seu ventre encoberto

O mesmo Deus é dentro como fora

Tudo pode e tudo obra com acerto;

E por isso ele teve esta senhora

Culpa original, por ser bem certo

Que o pecado; não entra onde Deus mora

(ANTT, processo 12958, fl. 93).

Por seu processo não conter sentença, ficamos impedidos de saber se Romão foi absolvido ou se foi condenado a cumprir algum tipo de pena. Se levarmos em consideração outros processos do mesmo período, podemos deduzir algo; como o processo do padre Antônio Carlos Monteiro. No Rio de Janeiro de 1764 temos, talvez, o crime de proposição herética mais significante do clero no Brasil. O padre de 33 anos teria dito, no ano anterior, em uma de suas missas que:

Que os céus, sol, lua e estrelas não foram criados por Deus, nem se movem por determinação sua, porque todo o seu movimento procede por obra da natureza; $e$ também diz que não há Deus, e se o há, que não toma providencias, porque se vê morrer um homem casado, ficando ao desamparo muitos filhos por crias, e que deixa viver outros que nenhuma falta faria se morressem; e também que há pobres miseráveis com bom procedimento e ricos com maus, e soberbos, e que se houvesse Deus, ou tivesse providencias, não sucederia assim. E também afirma que Cristo Senhor nosso era puramente homem e que foi o mais ladino que houve naquele tempo, em que andou pelo mundo, porque soube fingir muitas coisas, que o acreditaram a fazer uma lei (ANTT, processo $9697 \mathrm{fl} .13$ ).

Ainda havia a denuncia de que há anos estava amancebado com uma mulher e com ela teria dois filhos. O padre fora enviado para Lisboa e preso nos cárceres secretos da Inquisição. De todos os processos sobre os religiosos que pesquisei, sua sentença foi a mais rigorosa.

E assentou-se que o bem julgado pelos Inquisidores, Ordinários e Deputados em determinarem que the seja recebido ao grêmio e união da Santa Madre Igreja com cárcere e habito penitencial a arbitrio, em pena e penitencia de suas culpas vá ao Auto publico da fé e nele ouça sua sentença, e abjure seus heréticos erros em forma, e se declare que incorreu em sentença de excomunhão maior, em confissão de todos os seus bens para quem de Direito pertencerem, e nas mais penas contra semelhantes estabelecidas, e da dita excomunhão será absoluto in forma Eclésia; fique suspenso para sempre de suas ordens e inabilitado para obter benefícios eclesiásticos, tenha reclusão arbitraria nos cárceres do Santo Oficio, penitencias espirituais e instrução ordinária. Mandam que assim se cumpra. Lisboa 11 de Setembro de 1764 (ANTT, processo 9697 fl. 155).

Nos cárceres do Santo Oficio, o padre Antônio Carlos Monteiro continuou proferindo suas ideias heréticas e contestatórias. Refutando a virgindade de Nossa Senhora, dizia "que não cabia em juízo claro, que a sua mulher parindo, continuasse virgem”. "Que o Papa não tinha poder mais do que qualquer homem e, caso tivesse havido na terra um Vigário de Cristo, o que não era de crer, seria só São Pedro, porque depois dele os mais eram pecadores". "Não havia motivo para que homens 
confessassem a outros homens igualmente pecadores [clérigos], que nenhum poder tinham para absolver" (ANTT, processo 9697 fl. 160). Oito anos depois, em 1772, o padre continuava preso, mas, pedia através de uma carta que fosse absolvido e solto. Dizia estar "sofrendo algumas moléstias e que os médicos aviam pedido que fizesse exercícios, tomasse banho e respirasse ar puro" (ANTT, processo 9697 fl. 191). Pedia também que o mandassem para a cidade do Porto, para poder fazer companhia à sua mãe que estava "com mais de 80 anos" ". Seus pedidos foram atendidos. Esse "mal viver" de clérigos não era exclusivo do Brasil, com o clero de Portugal não era muito diferente. Em Lisboa no ano de 1661, o padre Pedro Barbosa Henriques, após ser perguntado por um cidadão sobre sua missa, afirmou "que Deus no seu lugar, não faria melhor" e também "que sua mãe deveria ser respeitada na terra como Nossa Senhora no céu" (ANTT, processo 143 fl. 10). A primeira frase incorreu as maiores notas de censura. Foi considerada escandalosa; mal soante; ofensiva. A segunda, indigna dos piedosos ouvidos dos fiéis. O processo foi arquivado e o padre condenado a ficar no cárcere "mais apertado" (ANTT, processo 143 fl. 43). Tanto os portugueses quanto os colonos nascidos na América portuguesa mantinham com Deus, Jesus Cristo, a Virgem e os santos, de uma forma geral, uma relação de grande intimidade e até de familiaridade, tratando-os, não raro, quando não os atendessem, com rudeza e aspereza. Um humor que não mostrava, necessariamente, uma descrença, mas apenas certa intimidade. Antônio Manuel da Silveira morador em Ilhéus na Bahia, de 60 anos de idade, em 1795 foi repreendido severamente e mandado para a missão de São Vicente de Paulo, após isso, foi posto em liberdade. Teria dito que:

\begin{abstract}
"Não havia inferno para castigo dos que ofendiam a Deus nesta vida. Que não era pecado a fornicação entre os homens $e$ mulheres e que livremente podiam ter relações sexuais entre pais e filhos, entre irmãos, pois foi assim que se começou a propagação do gênero humano. E que cristo e os apóstolos foram "fornicários" quando andaram pelo mundo" (ANTT, processo 8291, fl. 90).
\end{abstract}

Levando em consideração também o Regimento do Santo Oficio de 1774 podemos considerar que Romão Fagundes teve uma sentença branda devido a alteração do peso conferido a cada etapa processual; com a diminuição da importância dada à delação e a ampliação do direito de defesa do acusado. No mesmo Regimento há também uma redução das condutas relativas à jurisdição inquisitorial influenciado por ideais iluministas no pensamento português, além de concordar que a “confissão fulminava a possibilidade de aplicação de penas mais duras" (REGIMENTO, 1774, p. 932). O Santo Oficio português criminalizava o pecado mas, haviam casos que abriam em seus processos a possibilidade de misericórdia e reconciliação: justiça e misericórdia, tal como expresso nos estandartes inquisitoriais.

O que pode ser analisado dos depoimentos a respeito de Romão, é que buscava nos livros as respostas para os questionamentos que os padres não o satisfaziam. Não hesitava em expor suas ideias, era um homem libertino de consciências e práticas sexuais, "a análise de seu caso serve para descortinar os anseios, principais questionamentos e a postura da sociedade inquieta a qual fazia parte" (SOUSA, 2013, p. 9).

Nesse processo e em vários outros é possível notar algumas evidências de que os livros serviam para fundamentar as proposições. "Ataques ao Papa, à Inquisição, ao estado eclesiástico, além do entendimento de que a religião servia para repressão do homem na socie- 
dade, possuíam alguns pontos de convergência com posições defendidas em alguns livros proibidos" (VILLALTA, 2009, p. 123). Citando Anita Novinsky, Villalta mostra que a autora afirma que as criticas feitas ao catolicismo eram obras de uma "descristianização interior", "de uma mentalidade clandestina, subterrânea, desenvolvida por "uma camada da sociedade", ao longo e em resistência a séculos de repressão, mormente a inquisitorial" (VILLALTA, 1999, p. 337). Nessa "mentalidade" encontrar-se-iam subsumidos "uma postura iconoclasta contra os santos, contra o confessionário, contra o culto e as cerimônias, que eram ridicularizados e atacados juntamente com toda Igreja militante" (VILLALTA, 1999, p. 337).

Grande parte dos colonos brasileiros não eram possuidores de terras e privilégios, levavam uma vida humilde em meio a uma economia de subsistência familiar onde a alimentação muitas vezes era escassa. A vida nos vilarejos e no restante da colônia, como afirma Eneida Beraldi Ribeiro, era difícil e cara. Devido a isso, "não havia luxo, fartura ou ostentação" (RIBEIRO, 2006, p. 19), a vida do colono era baseada e guiada pelos princípios religiosos, se bem que por muitas vezes, estes princípios não eram seguidos devidamente como a Igreja concordava. Na leitura dos processos-crimes torna-se evidente a ausência de momentos de lazer ou diversão. Haviam os que jogavam, os que apostavam e muito pouco aqueles que liam. A grande maioria ocupava seu tempo ocioso conversando, ou como se encontra na documentação "em conversação", nas feiras, nas ruas, à porta das Igrejas e casas, sem preocupação com o que diziam até a chegada de uma das varias "ramificações" da Inquisição portuguesa. "Surgem ainda evidências de como tais heterodoxias surgiram da articulação entre debates orais, conversas e discussões juntamente com os livros, esses últimos serviram para legitimar ou dar um ar de erudição a certas proposições heréticas" (VILLALTA, 2009, p. 118).

Na primeira Visitação, foi enviado ao Brasil como agente do Santo Ofício, Heitor Furtado de Mendonça de aproximadamente trinta e cinco anos, além de licenciado, tinha ainda em seu currículo o título de desembargador real e capelão fidalgo do Rei. Era homem de foro nobre que passara por dezesseis investigações de limpeza de sangue ${ }^{5}$ para habilitar-se ao cargo inquisitorial. Desembarcou na Bahia em 9 de Junho de 1591, em sua comitiva vieram também D. Francisco de Sousa, recém nomeado para a Governança Geral, e Manoel Francisco, notário; também estava presente o meirinho Francisco Gouvêa, ajudante de ordens do visitador.

Em 28 de julho de 1591 tem início a Visitação do Santo Oficio ao Brasil.
[...] não sem grande pompa e cerimonial laudatório ao Santo Oficio e à pessoa de Heitor Furtado, presentes o bispo com seu cabido, os funcionários da Gover- nança e Justiça, vigários, clérigos e membros das confrarias, sem falar do povo que se acotovelou nas ruas da cida- de para acompanhar o cortejo inquisito- rial. Heitor Furtado veio debaixo de um pálio (sobrecéu portátil) de tela de ouro e, estando na Sé, recebeu um sem número de homenagens e discursos de louvor, inclusive de Marçal Beliarte, provincial dos jesuitas (VAINFAS, 1995, p. 25).

Após toda essa exuberante apresentação, Heitor Furtado deu início aos seus trabalhos como membro da Inquisição portuguesa: publicou o Edital da Fé e Monitório da Inquisição onde se encontravam a definição e caracterização dos crimes sob jurisdição inquisitorial. Após as publicações, o licenciado anunciou o Tempo

\footnotetext{
${ }^{5}$ Ao adotar os estatutos de limpeza de sangue no processo de admissão de novos membros em seus quadros, a Inquisição passou a controlar uma das clivagens estruturantes da ordem social do Antigo Regime português, que era a separação da sociedade entre cristãos-velhos e cristãos novos.
} 
da Graça, um período de até trinta dias no qual as pessoas poderiam confessar suas culpas sem sofrer algum tipo de pena corporal ou sequestro de bens. Aqui surge um problema para Heitor Furtado de Mendonça. O Visitador havia sido instruído e treinado para descobrir heresias nas mínimos detalhes em que se escondessem, "em mentes esclarecidas dos judaizantes. Nunca nos toscos engenhos de homens rudes como era a maioria dos mamelucos com quem se defrontava" (SIQUEIRA, 1978, p. 57).

Certas praticas, pela frequência com que eram relatadas, talvez lhe tivessem parecido comuns, coisas de somenos, exotismos de um meio estranho. Muitas coisas que devem ter ficado nos Cadernos de Lembranças ou que nem sequer terão sido anotadas, se analisadas acuradamente, talvez pudessem revelar os fermentos dissolventes para o Catolicismo еuropeu (SIQUEIRA, 1978, p. 57)

Ainda sobre os membros do clero, o descrédito em relação aos eclesiásticos talvez fosse atiçado também mais pelo número considerável de padres conhecidos pelo "mau viver". "Nas Minas setecentistas foram numerosíssimos, sempre envolvidos em rixas, defloramentos, concubinatos, raptos, jogatina, bebedeiras, desacatos aos fiéis" (SOUZA, 1986, p. 106). Uma Carta Régia de 9 de novembro de 1709 ordenava a expulsão de "todos os clérigos que se acharem nas Minas sem emprego necessário"6 e que realizassem alguma atividade discordante do seu estado eclesiástico. Essas medidas buscavam limitar o número de religiosos existentes nas Minas Gerais com o intuito de evitar o contrabando ilegal de ouro e preservar o "bom catolicismo" na região. ${ }^{7}$

Minas Gerais foi objeto de desejo por parte de seus colonizadores: controle e vigilância pesaram sobre sua terra para arrancar seus mais velados segredos. "Mas, não haveria de ser pelo ouro e diamante que celebrizaram o Eldorado e levaram a uma torrente de gente acotovelar-se na saga da mineração" (RESENDE; JANUÁRIO, TURCHETTI, 2011, p. 1). Os olhares que recaiam sobre as vilas e os lugares mais ocultos buscavam outra impenetrável, sigilosa e oculta face de Minas: os hereges. Buscando descobrir atitudes e os sentimentos mais íntimos, a vida privada das pessoas fora violada. Esse foi o objetivo sobre o qual se debruçou o Tribunal da Inquisição.

De acordo com as Constituições Primeiras do Arcebispado da Bahia, as visitações feitas pela Inquisição, "atentavam para o governo espiritual e temporal, cuidando da reverência do culto divino, a reforma dos costumes e a extirpação dos pecados" (VIDE, 1853, p. 14). Por isso, a visita deveria, "por meio de uma devassa eclesiástica, reconhecer os transgressores em seus "abusos e erros" e, então, proceder à "emenda", impingindo o castigo e o temor àqueles que ousassem não se submeter aos preceitos da Igreja Católica" (RESENDE, JANUÁRIO, TURCHETTI, 2011, p. 1). Como tantos outros casos da inquisição, é sensível a influência iluminista nas prédicas deste morador nas Minas considerado herege. Consumidor ávido desta cultura, ainda que à revelia das proibições religiosas, reelaborava-a de forma genial e produzia seus sonetos de uma forma legitimamente nativa. Ainda que a inclinação à libertinagem seja recorrente na colônia, é o estilo de Romão que salta aos olhos: o escárnio, o riso, o deboche.

Essas expressões proferidas por algum cristão ou não - refletiam pontos de vistas contrários aos artigos da fé que constituíam a essência do Cristianismo, contradizendo os dogmas, alavancando uma dúvida so-

\footnotetext{
${ }^{6}$ Ordens que se acham nos livros da Secretaria do Governo desta Capitania de Minas Geraes, deduzidas por ordem a títulos separados.

${ }^{7}$ Ver mais em: BOSCHI, Caio César. Os leigos e o poder: irmandades leigas e política colonizadora em Minas Gerais. 1. ed. São Paulo: Ática,1986, p. 80.
} 
bre a validez das orientações doutrinais, negando a palavra e os mandamentos divinos. Juan Antonio Garcia caracteriza as proposições como expressões proferidas por um cristão, “com visões opostas aos artigos da fé que constituem a essência da religião católica, os preceitos da Igreja ou os ensinamentos contidos nas Escrituras" (GARCIA, 1998, p. 6). As proposições heréticas, as criticas, as indagações e os questionamentos alcançavam certa profundidade, ao propiciarem uma relação entre heterodoxia e espiritualidade. "Mas, por outro lado, constituíam feroz contestação à autoridade da Igreja e do Estado e, por isso mesmo, à Inquisição. A teologia era uma questão de existência para estes homens e mulheres da época Moderna” (MATTOS, 2014, p. 137). Resumidamente, as proposições heréticas eram aquelas que se voltavam claramente contra qualquer uma das afirmações tidas como verdades católicas. Tal delito não consistia apenas em uma possível desvirtuação da ortodoxia, mas também, “em uma confusão e um abalo a quem as ouvia" (FLORES, 2013, p. 48). É dessa forma que os delitos verbais, até então da jurisdição dos Tribunais Ordinários, passaram a ser julgados pelo Tribunal do Santo Oficio da Inquisição. Tribunal este que foi o principal auxiliar da Igreja para deter os erros doutrinais e difundir os valores da Contrarreforma.

A punição de não tomar o nome de Deus em vão refere-se, uma vez mais, à importância e o perigo da palavra: a língua humana tem a capacidade de louvar e servir através da evangelização, mas também é capaz de ferir os privilégios reconhecidos pela divindade plantando falsidades, distorcendo sua natureza, atacando-a com ofensas (FOGELMAN, 2012, p. 94).

As proposições heréticas faziam parte de um pequeno grupo muitas vezes letrado e que compreendiam a gravidade do que proferiam tanto publicamente quanto no privado. Feitas publicamente, sua periculosidade aumentava, pois residia não somente na transmissão dos erros, mas também, “na invalidação da Igreja ante aos olhos da congregação, em virtude da pretensão de moldar as condutas e práticas destes" (FOGELMAN, 2012, p. 67). Dessa forma, a Igreja se encarregava de disciplinar e ensinar sobre os verdadeiros preceitos que deveriam ser seguidos, durante a missa, o sermão dava lugar às explicações de partes da palavra sagrada ou sobre algum tema mais específico. Mas, e quando as proposições eram ditas por um religioso? Os espaço e momentos propícios para isso podiam ser vários, desde o confessionário até mesmo em uma conversa informal na porta da Igreja, mas, o mais comum e que se fazia propagar para um maior número de gente, era o púlpito da Igreja.

O catolicismo, nos primeiros séculos de formação da sociedade brasileira, assumiu um caráter obrigatório. Viver na América portuguesa sem pertencer à religião Católica era uma tarefa das mais difíceis, o indivíduo deveria no mínimo demonstrar um certo respeito pelo credo romano $\mathrm{Na}$ concepção de Hoornaert, a vida cristã do povo passava por dois caminhos: aquele ligado ao grupo dos organizadores, ou seja, o do clero propriamente dito, e o outro, junto aqueles que viviam o cristianismo concretamente, o povo. A situação do clero no Brasil colonial era algo drástico, a começar pela ausência de vocação sacerdotal e a qualificação desses "profissionais".

Como afirma José Pedro Paiva, podemos explicar a situação precária do clero brasileiro se olharmos o clero de Portugal. É decorrente, comenta o autor, "da deficiente formação cultural e da ausência de vocação religiosa de boa parte deste corpo" (PAIVA, 2000, p. 205). Tornava-se algo comum encontrarmos cenários de "ausência de observância da regra - os votos de clausura, pobreza e até castidade eram frequentemente quebrados - bem como situações de indisciplina e um nível muito elementar de formação escolar, cultural e até religiosa" (PAIVA, 2000, p. 205). 
As Constituições primeiras do Arcebispado da Bahia $^{8}$ visando a boa índole de seu quadro clerical possui o livro Terceiro com doze títulos relacionados ao bom comportamento dos clérigos. O título I " $D a$ obrigação que tem os clérigos de viver virtuosa e exemplarmente” faz um resumo básico do que se tratam todos os outros onze títulos:

Quanto é mais levantado, e superior o estado dos Clérigos, que são escolhidos para o Divino ministério, e celestial militância, tanto é maior a obrigação que tem de serem Varões espirituais e perfeitos, sendo cada Clérigo que se ordena tão modesto e compondo de tal sorte suas ações, que não só na vida, e costumes, mas também no vestido, gesto, passos, $e$ praticas tudo nele seja grave e religioso, para que suas ações correspondam ao seu nome [...] (CONSTITUIÇÕES, 1707, fl. 175).

Em 1592 na cidade de Salvador, o padre Luiz do Couto foi denunciado por um lavrador de Taparica chamado Heitor de Barros por ter proferido que "não se metesse na cabeça que havia inferno, porque era somente um medo que assim se punha para não pecarem, mas que não havia inferno" (ANTT, processo 2553, fl. 4-5), após o denunciante dizer que tinha medo de dormir com negras e "ir parar no Inferno" (ANTT, processo 2553 , fl. 5). O lavrador também denunciou à Inquisição que, alguns anos atrás, o mesmo padre havia dito que "Cristo não sabia que havia de ressuscitar e que teria tido medo da morte" (ANTT, processo 2553, fl. 7). Perguntado pelo licenciado Heitor Furtado de Mendonça qual o motivo de ter dito tais coisas, respondeu que não se lembrava de nada, pois estava "perturbado por ter ingerido alguns copos de vinho, um vício que não largava”. Aqui temos um exemplo nítido da formação cultural e da ausência de vocação religiosa aborda- da por José Pedro Paiva (APIVA, 2000) e também como o inferno tomou conta da imaginação do colono e não apenas do europeu. Com a popularização do inferno, o batismo deixa de ser um instrumento que conduzia a vida eterna e a entrada no céu, o simples fato de ser cristão não dava mais garantias para gozar de uma vida de alegrias no paraíso. O Inferno aparece como um instrumento para controlar aqueles que tinham autonomia de si. Um simbolismo que, segundo Clifford Geertz, atua para estabelecer expressivas, profundas e longas “disposições e motivações nos homens através da formulação de conceitos de uma ordem de existência geral e vestindo essas concepções com tal aura de fatualidade que as disposições e motivações parecem singularmente realistas" (GEERTZ, 2008, p. 67).

\section{Conclusão}

É fundamental o conhecimento histórico na definição, redefinição e absorção das mudanças no campo das identidades pessoais e coletivas, fazendo com que a História participe do processo de construção das identidades sociais. Isso porque a História é um dos principais campos do conhecimento a oferecer os primeiros conjuntos organizados de ideias, informações e imagens sobre o grupo e o individuo no tempo, assim como oferece esses mesmo elementos para representarmos os "outros" que não pertencem ao nosso grupo em outros tempos e espaços. Os colonos brasileiros passavam por várias duvidas geradas pelas incertezas e dificuldades da vida, envoltas de inúmeros elementos simbólicos de origens variadas, "buscando a humanização do sagrado e resistência à imposição da pureza doutrinária" (SOUSA, 2013, p. 2).

\footnotetext{
${ }^{8}$ As "Constituições primeiras do Arcebispado da Bahia" impressa em Lisboa no ano de 1719 foi uma compilação de normas, para servir como a principal legislação eclesiástica no Brasil Colonial.
} 
Além das motivações multiculturais da península ibérica, imigrantes estrangeiros, principalmente das regioes protestantes, representavam um elo a essas ideias, também críticas à ortodoxia católica e a primazia do clero perante a sociedade. Essa influência não deixava de pesar nas formulações de proposições cotidianas em que qualquer pessoa poderia se contagiar com ideias difundidas por qualquer estrangeiro ou nas composições dos debates filosóficos (SOUSA, 2013, p. 2).

A importação de livros para as colônias teve papel importante na propagação de novas ideias e produção de novos conceitos, gerando um problema tanto para Portugal quanto ao Brasil com a quebra do Index Librorum Prohibitorum ${ }^{9}$. Indiferente também da intenção do leitor, "os livros sempre eram lidos de maneira criativas, e os leitores entendiam o conteúdo à sua maneira e o interpretavam dentro de suas realidades pessoais" (SCHWARTZ, 2009, p. 221). Dessa maneira, os leitores produziam suas próprias conclusões e as partilhavam com aqueles que não sabiam ler, agindo como apaziguadores de seus sofrimentos e elo entre as culturas erudita e popular.

O solo colonial era ambiente fértil para florescimento de dúvidas e dissidências, em sua grande maioria trazida por esses povos que em si portavam já tendência ao relativismo. Os principais questionamentos há muito já haviam perdido parte de suas origens, mas continuavam a se disseminar pela população, verbalizando seus conflitos e anseios cotidianos, eram racionais e tendiam a buscar uma explicação plausivel para a realidade muito diversa da que lhes era imposta nos púlpitos (SOUSA, 2013, p. 4).

A Igreja, buscando frear esses "apaziguadores", criava cartilhas, manuais simples e baratos de leitura e catecismos para a pequena porcentagem daqueles que sabiam ler. Segundo Stuart Schwartz, foram publicados nas Américas cerca de 137 catecismos nas Américas, "sem mencionar a tradução de catecismos estrangeiros" (SCHWARTZ, 2009, p. 222). Mas o autor ainda lembra que a leitura abria as portas à curiosidade. As duvidas e questionamentos cresciam a cada dia, "e boa parte da responsabilidade cabe à imprensa, cuja forma clara e agradável convida à leitura, à diferença dos manuscritos anteriores, que eram mais difíceis e menos numerosos" (MARAVALL, 1972, p. 67). A proposição herética foi um desvio em relação ao qual a Igreja e o Estado se viram obrigados a proteger a sociedade contra a possível ira de Deus.

Para Maureen Flyn (1995), a fala garantia a realidade do pensamento, era assim que a Inquisição enxergava tudo o que era dito pelos blasfemadores e propositores. Compreendiam a fala como uma extensão do pensamento e apresentação de convicções internas. E mesmo assim ainda havia quem falasse por descuido ou convicção. Mas, trabalhar com processos-crimes nunca foi algo fácil. As condições em que os depoimentos eram obtidos, o medo constante de ser torturado, a desigualdade intelectual entre inquisidores cultos e presos muitas vezes analfabetos, e as inúmeras estratégias dos acusadores e das testemunhas dificultam o uso desses registros. Nem sempre as confissões eram necessariamente expressões de uma verdadeira crença, e tampouco as denuncias e acusações vinham isentas de outras motivações.

Pode-se afirmar que Romão Fagundes continuou homem rico até a sua morte. Na abertura de seu testamento, no mesmo ano em que faleceu, deixou todas suas posses para suas duas filhas Angélica Rosaura do Amaral e Jacinta Teodora do Amaral, e para sua viúva 
Maria José da Encarnação. Os bens deixados foram uma casa no arraial de Perdões denominada "A Estalagem" avaliada em 22.000 réis, 47 alqueires de terras avaliadas em 235.000 réis, a Fazenda Cachoeira com 75 alqueires avaliada em 692.000 réis, uma porção de terras na fazenda Parnazo com 70 alqueires de plantações avaliadas em 560.000 réis, terras no córrego Embira avaliadas em 108.000 réis, a Fazenda Estiva com 156 alqueires de terras de cultura mais 142 alqueires de campos avaliados em 1.496.000 réis e algumas terras de cultura, campos e cerrados nas Amoreiras com 81 alqueires avaliadas em 138.000 réis $^{10}$. Totalizando são 3.251,00 réis, uma quantia enorme se fosse convertida para os nossos valores atuais.

Vejo que Romão Fagundes do Amaral por ser tão rico e possuidor de grandes propriedades, recebeu uma pena que podemos considerar leve. Acredito que sua sentença foi pagar todo o custo do processo, receber instruções sobre a fé católica e sofrer algumas penitências espirituais. A retratação diante da Mesa do Santo Oficio e os poemas e sonetos que escreveu mostrando toda sua religiosidade, contribuíram para isso. A construção da capela do Senhor Bom Jesus dos Perdões em sua fazenda vinte anos depois, pode ter sido de alguma forma, uma maneira de iludir a Igreja. Uma amostra de que teria mudado e se tornado um homem mais religioso.

Indiferente do século, a luta contra o pecado e o pecador permaneceu, mas em moldes distintos. Não é possível afirmar, com certeza, o nome de todos os nascidos e moradores do Brasil que foram presos pela Inquisição. De qualquer maneira, o que restou do período foram os registros de um Brasil ainda dependente de sua colônia e dos hábitos e cultura de seu povo. O Brasil havia se transformado "numa próspera colônia de grandes fazendas para onde os colonizadores portugueses, depois de comerciar com e mais tarde escravizar a população indígena, começaram a importar escravos africanos" (SCHWARTZ, 2009, p. 181) formando assim, uma sociedade com alto grau de miscigenação racial e principalmente cultural.

Como tantos outros casos da inquisição, é sensível a influência iluminista nas prédicas deste morador nas Minas considerado herege. Consumidor ávido desta cultura, ainda que à revelia das proibições religiosas, reelaborava-a de forma genial e produzia seus sonetos de uma forma legitimamente nativa. Ainda que a inclinação à libertinagem seja recorrente na colônia, é o estilo de Romão que salta aos olhos: o escárnio, o riso, o deboche.

\footnotetext{
${ }^{10}$ Projeto Compartilhar. Inventário de Romão Fagundes do Amaral, 1825 Cx: 428.
} 


\section{Referências bibliográficas}

\section{Fontes primárias:}

A.N.T.T. Inquisição de Lisboa. Processo 2.553

A.N.T.T. Inquisição de Lisboa. Processo 8.291

A.N.T.T. Inquisição de Lisboa. Processo 8.821

A.N.T.T. Inquisição de Lisboa. Processo, 8.502

A.N.T.T. Inquisição de Lisboa. Processo 9.697

A.N.T.T. Inquisição de Lisboa. Processo 11.111

ANTT. Inquisição de Lisboa, processo 12.958

VIDE, D. Sebastião Monteiro da. Constituições Primeiras do Arcebispado da Bahia [1707]. São Paulo: Tipografia 2 de dezembro de Antonio Louzada Antunes, 1853.

REGIMENTO do Santo Oficio da Inquisição dos reinos de Portugal, ordenado com o real beneplácito, e régio auxilio pelo eminentíssimo, e reverendíssimo senhor cardeal da Cunha, dos conselhos de estado, e gabinete de sua majestade, e inquisidor geral nestes reinos, e em todos os seus domínios. Impresso em Lisboa na oficina de Miguel Manescal da Costa. Ano 1774. (Microfilme nº 4 da Biblioteca Nacional de Lisboa, Sala Geral).

Livros, periódicos e artigos:

ALEJANDRE, Juan Antonio; TORQUEMADA, María Jesús: Palabra de hereje. La Inquisición de Sevilla ante el delito de proposiciones, Séville, Universidad, 1998.

BAKHTIN, Mikhail. A cultura popular na Idade Média e no Renascimento: o contexto de François Rabelais. Brasília. São Paulo: EdUnb, 1987.

BETHENCOURT, Francisco. História das Inquisições - Portugal, Espanha e Itália - Séculos XV-XIX. São Paulo: Companhia das Letras: 2000.

CANCELA, Francisco. De volta ao tema da primeira prisão da Inquisição no Brasil: balanço historiográfico e novos olhares sobre a experiência de Pero do Campo Tourinho. Revista Pindorama, v. 1, p. 1-20, 2010.

FLORES, Georgina Indira Quiñones. El clero y el delito de proposiciones en Zacatecas: Los errores manifestados en los sermones, siglos XVI y XVII. Boletín Americanista, Barcelona, n. 67, p. 47-69, 2013.

FLYNN, Maureen. "Blasphemy and the play of anger in sixteenth.century Spain", in Past and Present, n. 149, Oxford, Oxford University Press, nov. 1995.

FOGELMAN. Patricia. "Son unas puercas todas las imágenes y unos pedazos de palo": Manuel de Coito, escultor portugués acusado por blasfemias ante el Santo Oficio de la Inquisición. Buenos Aires, siglo XVII, en la Revista "População e Sociedad", del Centro de Estudos da Populaçâo, Economia e Sociedade (CEPESE) de Porto (Portugal) n. 20. Porto, 2012.

GARCÍA, Juan Antonio Alejandre. Inquisición Sevillana y proposiciones heréticas :la Ley de Dios y los pecados de la carne. Historia. Instituciones. Documentos, n. 25, p. 1-12, 1998.

GEERTZ, Clifford. A Interpretação das Culturas. 1 ed. 13ª reimpressão. Rio de Janeiro: LTC, 2008.

HOONAERT, Eduardo. Formação do Catolicismo Brasileiro-1550-1800. 2 ed. Rio de Janeiro. Editora Vozes. 1978.

MARAVALL, José Antonio. La oposición política bajo los Austrias. Barcelona: Ariel, 1972. 
MARCOCCI, Giuseppe; PAIVA, José Pedro. História da Inquisição portuguesa (1536-1821). Lisboa: A Esfera dos Livros, 2013.

MATTOS, Yllan de. "Me tome o Santo Ofício no cu": injúrias populares, críticas e vocábulos da praça pública contra a Inquisição portuguesa (séculos XVI-XVIII). In: ASSIS, Angelo Adriano Faria de; LEVI, Joseph Abraham; MANSO, Maria de Deus Beites. (Org.). A expansão: quando o mundo foi português. 1ed.Viçosa / Braga / Washington: Ed. Évora, 2014.

MENEZES, Raul Goiana Novaes. Palavras Torpes: Blasfêmia na Primeira Visitação do Santo Ofício às partes do Brasil. (Pernambuco, 1593-1595). 2010. Dissertação (Mestrado) - Curso de História, Universidade Federal de Pernambuco, Recife, 2010.

NOVINSKY, Anita Waingort. A Inquisição. 2 ed. São Paulo: Brasiliense, 1983.

PAIVA, José Pedro. Os mentores." frades e freiras. In: AZEVEDO, Carlos Moreira (Dir.). História religiosa de Portugal. Lisboa: Círculo de Leitores, 2000.

PIERONI, Geraldo. Os Excluídos do Reino. 2 ed. Brasília: Unb, 2006.

RESENDE, Maria Leônia Chaves de; JANUÁRIO, Mayara Amanda; TURCHETTI, Natália Gomes. De jure sacro: a inquisição nas vilas d'El Rei. Varia História, Belo Horizonte, v. 27, n. 45, jun. 2011.

RIBEIRO, Eneida Beraldi. Bento Teixeira e a "Escola de Satanás": O Poeta que teve a "prisão por recreação, a solidão por companhia e a tristeza por prazer". 2006. 305 f. Tese (Doutorado) - Curso de História, Departamento de História Social, Universidade de São Paulo, São Paulo, 2006.

SCHWARTZ, Stuart B.. Cada um na sua lei: Tolerância religiosa e salvação no mundo atlântico ibérico. Bauru: Edusc, 2009.

SOUSA, Rafael José de. "Um Dedo do Gigante": proposições e blasfêmias nas minas setecentistas. In: II Simpósio Internacional de Estudos Inquisitoriais Salvador, 2013, Salvador. Anais Eletrônicos Simpósio Internacional de Estudos Inquisitoriais: História e Historiografia. Cachoeira: UFRB, 2013.

SOUZA, Laura de Mello e. O Diabo e a Terra de Santa Cruz. São Paulo: Companhia das Letras, 1986.

VAINFAS, Ronaldo. A Heresia dos Índios: catolicismo e rebeldia no Brasil colonial. São Paulo: Companhia das Letras, 1995.

VAINFAS, Ronaldo. Trópico dos Pecados: moral, sexualidade e inquisição no Brasil Colonial. Rio de Janeiro: Campus, 1989.

VILLALTA, L. C. O que se fala e o que se lê: língua, instrução e leitura. In: SOUZA, Laura de Mello e. (Org.). Históra da vida privada no Brasil: cotidiano e vida privada na América portuguesa. 1ed.São Paulo: Companhia das Letras, 1997.

VILLALTA, Luiz Carlos. Montesquieu's Persian Letters and reading practices in the Luso-Brazilian World. In: PAQUETE, Gabriel. (Org.). Enlightened Reform in Southern Europe and its Atlantic Colonies, c. 1750-1830. Farnham: Ashgate, 2009.

VILLALTA, Luiz Carlos. O cenário urbano em Minas Gerais setecentista: outeiros do sagrado e do profano. In: Termo de Mariana: História e Documentação. Mariana: Imprensa universitária da UFOP, 1988.

VILLALTA, Luiz Carlos. Reformismo ilustrado, Censura e Práticas de Leitura: os usos do livro na América Portuguesa. São Paulo: FFLCH-USP, 1999 (Tese de doutoramento em História), USP-1999. 